Article

\title{
Effect of Drying Methods on Bioactive Compounds and Antioxidant Capacity in Grape Skin Residues from the New Hybrid Variety "BRS Magna"
}

\author{
Gabriela Viana da Silva ${ }^{1}$, Bruna Aparecida Souza Machado ${ }^{2}$, Walkia Polliana de Oliveira ${ }^{1}$, \\ Camilla Fernanda Godinho da Silva ${ }^{1}{ }^{(D}$, Cedenir Pereira de Quadros ${ }^{3}$, Janice Izabel Druzian ${ }^{1}$, \\ Ederlan de Souza Ferreira ${ }^{1, *(D)}$ and Marcelo Andrés Umsza-Guez ${ }^{4, *(\mathbb{D}}$ \\ 1 School of Pharmacy, Federal University of Bahia (UFBA), Salvador 40170-115, Bahia, Brazil; \\ gvstecnologa@yahoo.com (G.V.d.S.); walkia2010@hotmail.com (W.P.d.O.); \\ camillagodinho@gmail.com (C.F.G.d.S.); janicedruzian@hotmail.com (J.I.D.) \\ 2 Technology College, National Service for Industrial Learning (SENAI/CIMATEC), \\ Salvador 41650-010, Bahia, Brazil; brunam@fieb.org.br \\ 3 School of Pharmacy, Federal University of the São Francisco Valley (UNIVASF), \\ Petrolina 56300-000, Pernambuco, Brazil; cedenir.quadros@univasf.edu.br \\ 4 Department of Biotechnology, Health Science Institute, Federal University of Bahia (UFBA), \\ Salvador 40170-115, Bahia, Brazil \\ * Correspondence: ederlan.ferreira@ufba.br (E.d.S.F.); marcelo.umsza@ufba.br (M.A.U.-G.); \\ Tel.: +55-71-99231-3184 (E.d.S.F.); +55-71-99285-9330 (M.A.U-G.)
}

Academic Editors: Maria Beatriz Prior Pinto Oliveira and Rita Carneiro Alves Received: 23 July 2020; Accepted: 11 August 2020; Published: 14 August 2020

\begin{abstract}
The effects of the drying process using the conventional oven and freeze-drying on the thermogravimetric profile, proximate composition, color parameters, individual bioactive compounds, and antioxidant activity in the grape residue (skin) were evaluated. Twenty individual phenolic compounds were identified, where a variation in concentration was observed for flavonols, stilbenes, phenolic acids, flavonoids, procyanidins, and particularly anthocyanins (malvidin-3,5-di-O-glucoside of $253.2-536.9 \mathrm{mg} / \mathrm{kg}$ ) due to the drying process. Drying in a conventional oven caused a decrease of $23 \%$ of the total polyphenols. The skin of the BRS magna grape has a high concentration of total phenolic content of 489.5-148.3 mg.GAE/100 g, total anthocyanin content of 124.9-260.1 mg.CE/100 g, and total flavonoid content of $12.7-26.0 \mathrm{mg} . \mathrm{QE} / 100 \mathrm{~g}$. The results of free radical scavenging activity $\left(1.26-4.91 \mu \mathrm{g} / \mathrm{mL}\right.$, as $\left.\mathrm{EC}_{50}\right)$ and ferric reducing antioxidant power $(82.93-184.10 \mu \mathrm{mol} / \mathrm{g}$ of skin as equivalent to $\mathrm{Fe}_{2} \mathrm{SO}_{4}$ ) indicate high antioxidant activity, independently of the drying process applied. It was concluded that, if the application is directed to anthocyanin compounds, the use of lyophilization is recommended. On the other hand, if the interest is in bioactive compounds that exert antioxidant activity, conventional oven-drying can be used.
\end{abstract}

Keywords: Vitis vinifera; agro-food waste; polyphenols; conventional oven; freeze-drying

\section{Introduction}

Today, the challenge of the social, economic, and environmental impacts of food waste has become an urgent issue globally. The main causes of food waste or loss are the production, processing, retail, and consumption stages [1].

In this sense, the sustainable exploitation of waste will be a useful strategy with the aim of reducing environmental contamination and as an alternative to reducing the carbon footprint in the entire production process [2]. In addition, sustainable solid waste management is crucial for the prevention of infectious diseases, as risk factors for vector-borne diseases [3]. One of the current challenges is the 
processing of these residues for the elaboration of new products, used as ingredients [4], improvers of technological-functional properties [5], and for nutritional enrichment [6], which can reduce its negative impacts and obtain products with high added value [7]. In this context, the viticulture industry is included, as it generates a large amount of waste. Approximately, $20-30 \%$ of the weight of the processed grapes (juice, jams, wine, and raisins) remains as waste, consisting mainly of parts of stem, skin, and fruit seeds. Therefore, the wine industry produces millions of tons of waste per year, which represents a waste management issue, both ecologically and economically [8].

Grape skins are the main residue of viticulture, considered a great source of polyphenol compounds, such as flavonoids, anthocyanins, phenolics, and resveratrol. In fact, grape residue (skin) has a considerable amount of bioactive substances. This residue is attributed several protective and biological effects, such as antioxidant, antimicrobial, anti-tumor, anti-obesity, and anti-diabetes effects, in addition to helping to prevent neurodegenerative and cardiovascular diseases and having a prebiotic function in the intestinal microbiome [9-11].

The presence of these bioactive compounds in grape skins residues can add value due to the potential for more noble applications, whether in the food, pharmaceutical, or cosmetic industry [7]. Therefore, there is interest in applying grape by-products to fortify foods or as ingredients in products that contain high levels of bioactive compounds with these possible health benefits [12]. In addition to being attractive to health, the extracts have been widely used for the preparation of dehydrated natural dyes, mainly anthocyanins and applied to foods [13]. However, it is essential to know the chemical characteristics of the matrix (grape skin) and, above all, to understand the techniques for extracting these compounds, avoiding significant losses/damages to the compounds of interest [14].

Generally, dehydration techniques are commonly applied for the treatment of grape skin residues, taking into account the conditions of the process to preserve the compounds of interest (polyphenols). The most traditional method is dehydration in a conventional drying oven under different temperature and time conditions [15]. However, due to the long drying time often required, these methods can cause hydrolysis, oxidation, and degradation of the compounds of interest [16]. Some studies have evaluated the effects of different methods of thermal dehydration on color, phenolic, and antioxidant properties of fruit skins $[5,17,18]$.

Some unconventional methods, such as dehydration by freeze-drying and spray-drying methods, have been proposed to maintain the total content of polyphenols and the antioxidant effect of fruits and their derivatives, due to the preservation of thermolabile compounds, and to promote the conservation of longer storage times [5]. However, there is little information about the effect of drying temperatures used in the profile of the phenolic compounds of interest present in grape skin residues, and correlations with other parameters (color, antioxidant capacity, etc.), especially in recently developed hybrid varieties.

The "BRS magna" grape is a new hybrid variety obtained from the genetic crossing of "BRS Rubea" and "IAC 1398-1321 (Traviú)" developed by the Brazilian Agricultural Research Corporation used mainly for juice production in the São Francisco Valley region (between Petrolina and Juazeiro, Brazil), but there is still not much information about this variety, including the by-product (bark). It is a possible raw material for research on its use in the preparation of new foods or as a fortifying ingredient (bioactive compounds). Therefore, the aim of this study was to compare the effects of dehydration using the conventional oven-drying and freeze-drying process on the polyphenols content and antioxidant capacity in "BRS magna" grape skin residues. Quantitative and qualitative changes in individual phenolic compounds in fresh and dehydrated samples were determined using HPLC-DAD-FD. In addition, alterations in color parameters; content of total phenolics (CTP), total anthocyanins (CTA), and total flavonoids (CTF); antioxidant activity; and the correlation among these were also evaluated.

\section{Results and Discussion}

Currently, an incipient part of the residues derived from industrial grape processing is used to produce different products, from the process of re-fermentation of beverages and distillation, 
animal feed, and fertilizers [7]. However, the largest amount is discarded and incinerated, making it an important economic issue, in addition to a significant environmental problem [3]. On the other hand, these agri-food residues (fruits, vegetables, etc.) present an opportunity for commercial exploitation [17], in the form of new products in the food industry (natural dye, as a food/nutritional quality enhancer) $[9,11,13,19,20]$; in the pharmaceutical industry (functional supplements) [21-23]; in the cosmetic industry (products with antioxidant and photoprotective effects and inhibition of dermal proteases) [24].

In fact, some studies have shown the use of grape skins (fresh or dehydrated) as a supplementary source of phenolic compounds [4] in food products (e.g., bakery products such as cereal bars, muffins, and cookies; dairy products such as cheese and yogurt; and seafood, purees, and infusions) [25], while grape skin extracts can be used in drinks [5]. However, the exploitation of grape residues is scarce mainly due to its high moisture content, as it causes deterioration and degradation of valuable compounds [12].

\subsection{Proximate Composition}

In this study, the effects of dehydration were compared using conventional oven-drying and the lyophilization process on the content of polyphenols and the antioxidant capacity in grape skin residues of the "BRS magna" variety. The proximate composition of the BRS magna bark residues is shown in Table 1. There were no statistically significant differences $(p>0.05)$ between the skins in the parameters of ash, crude proteins, total lipids, fibers, and carbohydrates, which shows that the drying procedures did not cause degradation or change in the composition of the residue, as they preserved nutritional attributes.

Table 1. Proximate composition of dehydrated BRS magna grape skin residue using conventional oven-drying and freeze-drying methods.

\begin{tabular}{lcccc}
\hline \multirow{2}{*}{$\begin{array}{c}\text { Parameters } \\
\text { (\% Dry Weight) }\end{array}$} & Fresh Peel & Oven-Drying & Freeze-Drying & $\boldsymbol{p}$-Value \\
\cline { 2 - 5 } & $7.0 \pm 0.2$ & $7.0 \pm 0.8$ & $7.2 \pm 1.2$ & 0.098 \\
\hline Protein & $6.6 \pm 0.2$ & $6.4 \pm 0.5$ & $5.1 \pm 0.6$ & 0.058 \\
Ash & $2.9 \pm 0.4$ & $2.9 \pm 0.1$ & $3.3 \pm 0.2$ & 0.054 \\
Total lipids $_{\text {Total Carbohydrate }}{ }^{\dagger}$ & $83.5 \pm 0.8$ & $83.8 \pm 0.6$ & $84.5 \pm 0.9$ & 0.063 \\
Crude fiber & $35.4 \pm 2.0$ & $38.0 \pm 3.6$ & $41.6 \pm 1.8$ & 0.082 \\
\hline
\end{tabular}

$\ddagger$ The values of mean \pm standard deviation (SD) correspond to averages from three samples. ${ }^{\dagger}$ Defined by the difference between 100 and the sum of the percentages of other components, as shown in the Section 3.

The residue has a high amount of carbohydrates (about $83.5 \%$ ), of which a considerable part of fibers (about 38\%), proteins (about 7\%), and ash (about 6.5\%). Because of this, some studies have developed low-calorie foods, with a higher content of fiber, ash, and protein, using fruit skin residues to enrich these products $[4,6,26]$. Recently, Falcão et al. [6] elaborated an umbu bark jam (Spondias tuberosa) and Amorim et al. [4] developed a functional food ingredient enriched with polyphenols (extract based on grape skin variety Syrah) that showed a significant increase in nutritional properties, i.e., protein, ash, and concentrations of total phenolic compounds.

\subsection{Thermogravimetric Analysis}

Figure 1 traces the profile of TG and DTG curves during the combustion process of "BRS magna" skin residues. There were differences in the thermogravimetric parameters between the fresh skin and the materials obtained by drying $(p<0.05)$, but between the last two the behavior was similar. One explanation for the difference observed is that the fresh skin residue has the highest moisture content $(76.1 \pm 0.7 \%)$ when compared to other residues, which were subjected to conventional drying at $65^{\circ} \mathrm{C}$ $(4.6 \pm 0.1 \%)$ and dehydration by lyophilization $(9.0 \pm 0.1 \%)$. 


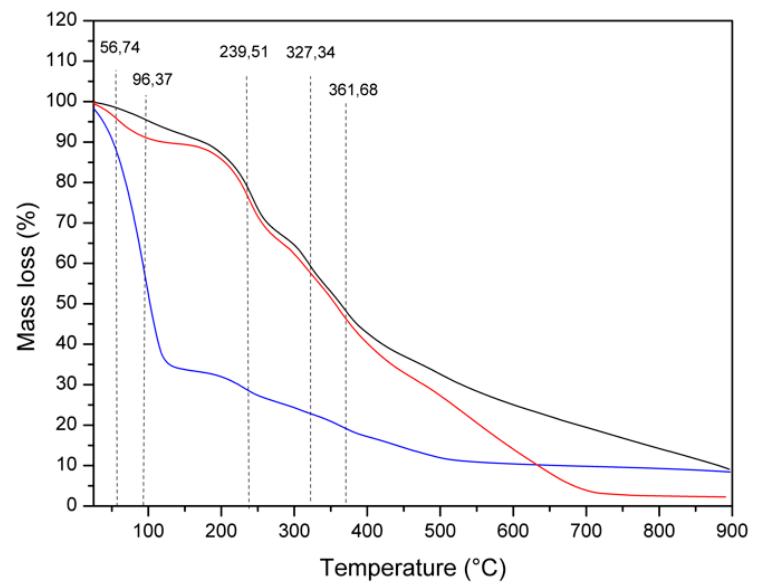

(a)

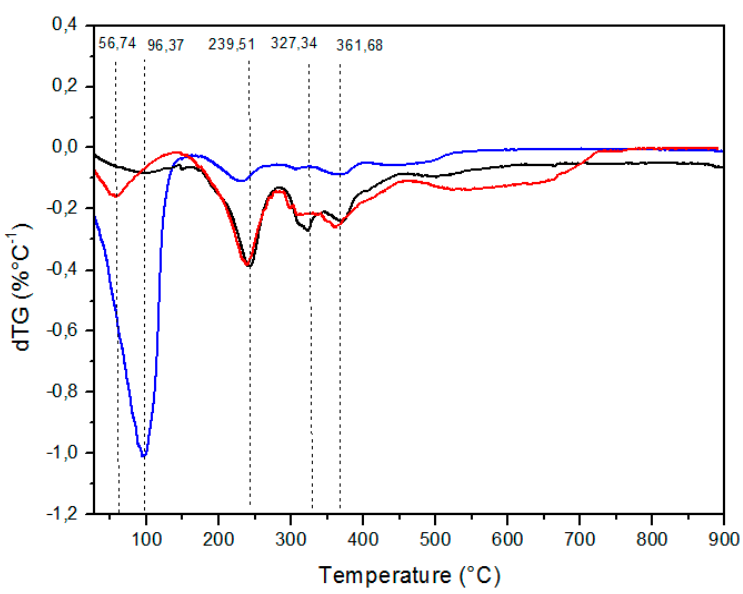

(b)

Figure 1. Thermogravimetric curve (TG) analysis (a) and for derivative weight dTG (b) of dehydrated samples of BRS magna grape skin residue using conventional oven-drying and freeze-drying methods. The profiles shown as blue, red, and black lines represent the fresh skin, conventional oven-drying, and freeze-drying processes, respectively.

As can be seen in Figure 1a, the first thermal mass loss event (TG) occurred at a temperature of $96{ }^{\circ} \mathrm{C}$ (onset), with a weight loss of $66.9 \pm 3.7 \%$ and $23.2 \pm 1.5 \%$; then at $239{ }^{\circ} \mathrm{C}$ (onset), with a $9.5 \pm 0.2 \%$ reduction in mass and $27.1 \pm 1.9 \%$; close to $327{ }^{\circ} \mathrm{C}$ (onset), with a decrease of $4.3 \pm 0.3 \%$ and $12 \pm 0.7 \%$; and finally at $362{ }^{\circ} \mathrm{C}$ (onset), with a reduction of $11.9 \pm 1.1 \%$ and $37.9 \pm 2.6 \%$, respectively, for fresh and dried samples $(p<0.05)$. The samples submitted to conventional drying and dehydration by lyophilization showed a smooth curve, indicating that the materials underwent decomposition during the formation of gaseous products. These results are close to those found by Gowman et al. [27] for the TG behaviors of grape and apple residues generated during the production of juice and wine, which also observed smooth curves, with the presence of peaks due to the evaporation of water and its other components.

In Figure 1b, the DTG curves are shown, where it was possible to observe that there are four well-defined mass losses, which allow the identification of the combustion stages [28]. The first derivative is attributed to the drying stage, occurring in the moisture content of the skin waste evaporation, characterized by a peak around $102{ }^{\circ} \mathrm{C}$ in the DTG curves (see Figure $1 \mathrm{~b}$ ). In the second and third events at the temperature range of $190-320^{\circ} \mathrm{C}$, the devolatilization phase occurred, which is characterized by a peak of around $246{ }^{\circ} \mathrm{C}$, in the DTG. In this stage, the peak is due to the oxidation of hydrogen present in organic matter, as well as the release of volatile compounds from this decomposition. In this sense, the peaks observed at the beginning of $214{ }^{\circ} \mathrm{C}$ and $311^{\circ} \mathrm{C}$ in the DTG are attributed to the degradation temperatures of hemicellulose and cellulose, respectively [27]. The fourth thermal event at $372{ }^{\circ} \mathrm{C}$ in the DTG marked the beginning of the coal oxidation stage [28], but a discreet and poorly defined peak was observed compared to the main ones. Even at this stage, the peak is due to the degradation temperature of lignin. These results are close to those reported for the DTG for grape and apple residues that showed peaks due to the degradation of hemicellulose at 267 and $260{ }^{\circ} \mathrm{C}$, cellulose at 340 and $335^{\circ} \mathrm{C}$, and lignin at 378 and $383^{\circ} \mathrm{C}$, respectively [27]. The dry skin residue of the BRS magna grape, regardless of the dehydration process carried out (conventional oven-drying or freeze-drying), proved to be thermally stable for most applications in industries, which are dependent on temperature.

\subsection{Color Parameters}

Table 2 shows the changes in color parameters due to the effect of oven-drying and freeze-drying. All samples showed characteristic red grape color in the values of $\mathrm{L}^{*}, \mathrm{C}^{*}$, and $\mathrm{H}^{\circ}$. However, there were 
statistically significant differences between treatments, where it is observed that the $L^{*}$ and $C^{*}$ indexes varied from 32.8 to 39.3 and 7.0 to 10.7 , which represented increases of $6.4 \%$ and $19.8 \%(p<0.05)$ and $8.6 \%$ and $52.9 \%(p<0.05)$ in oven-dried and freeze-dried materials, respectively, compared to fresh skin.

Table 2. Effect of the drying process using conventional oven-drying and the freeze-drying considering lightness $\left(\mathrm{L}^{*}\right)$, hue angle $\left(\mathrm{H}^{\circ}\right)$, and chromaticity $\left(\mathrm{C}^{*}\right)$ parameters of the BRS magna grape skin residue.

\begin{tabular}{ccccc}
\hline \multirow{2}{*}{$\begin{array}{c}\text { Parameters } \\
\text { (\% Dry Weight) }\end{array}$} & Fresh Peel & Oven-Drying & Freeze-Drying & $p$-Value \\
\cline { 2 - 5 } & $32.8 \pm 0.6^{\mathrm{c}}$ & $34.9 \pm 0.1^{\mathrm{b}}$ & $39.3 \pm 0.2^{\mathrm{a}}$ & $<0.001$ \\
$\mathbf{L}^{*}$ & $7.0 \pm 0.5^{\mathrm{c}}$ & $7.6 \pm 0.1^{\mathrm{b}}$ & $10.7 \pm 0.1^{\mathrm{a}}$ & $<0.001$ \\
$\mathbf{C}^{*}$ & $0.4 \pm 0.1$ & $0.5 \pm 0.1$ & $0.4 \pm 0.1$ & 0.420 \\
$\mathbf{H}^{\circ}$ &
\end{tabular}

$\ddagger$ The values of mean \pm standard deviation (SD) correspond to averages from three samples. Different letters on the same line indicate significant differences between the values $(p<0.05)$.

These results are close to those found by Natividade et al. [29] for parameter $L^{*}$ with values from 38.3 to 38.9 for the residues of Isabel grapes dried by oven and freeze-drying methods, respectively. In addition, Pedroza et al. [5] showed that drying in an oven at $60^{\circ} \mathrm{C}$ promoted changes in the shade of red (from $0 \%$ to $15 \%$ ) and color intensity (from $0 \%$ to $100 \%$ ) of the skin residues Bobal, Garnacha Tintorera, and Cabernet Sauvignon grapes. In another study, Ruttarattanamongkol et al. [17] observed that drying by hot air at $70{ }^{\circ} \mathrm{C}$ in orange-fleshed sweet potato and purple-fleshed sweet potato increased $\mathrm{L}^{*}$ values by about $9-74 \%$ compared to those in natura. There were no differences in the $\mathrm{H}^{\circ}$ parameters between oven-drying and freeze-drying.

Color loss is a natural process that occurs with all types of fruits and vegetables due to chemical and biochemical transformations related to the content of polyphenols and the presence of oxygen [13]. However, these changes are particularly important for food, because color is an important quality parameter that can influence consumer preferences [6]. Despite this, many agro-residues can be used as a source of dehydrated pigments and also have other effects on food products, e.g., antioxidant and antimicrobial activity $[20,23]$.

Previous studies on dehydration and characterization of grape skins residues showed favorable parameters for the release of color compounds, polyphenols, and aromas $[4,5,12,16]$. Thus, it is possible to observe that both the dehydration process by conventional oven-drying and freezing improved the color attributes of the BRS magna grape skin residues. Pedroza et al. [12] evaluated the addition of different dehydrated grape skins in young and aged reds to compensate for the loss of color before bottling. The results show that, after adding the skins, the color intensity of the wines increased by an average of $11 \%$ and a maximum of $31 \%$, with a predominance of the red component. In addition, the average total increase in polyphenols was $10 \%$, with a maximum value of $20 \%$. In this study, mixtures of dehydrated grape skins were useful to improve the color and polyphenols profile of red wines, considering them as a useful tool to correct color loss before bottling.

\subsection{Identification and Quantification of Phenolic Compounds}

Table 3 shows the effect of conventional kiln drying and freeze-drying on individual phenolic compounds from the BRS magna grape skin residues. It is possible to observe from the total of all quantified compounds that conventional oven-drying $(p<0.05)$ caused a $23 \%$ decrease in the total polyphenols. However, this effect was not seen in the lyophilization process.

Twenty-seven phenolic compounds were identified in the samples. There were statistically significant differences between treatments, with variation between anthocyanins, flavonols, stilbene, phenolic acids, flavanols, and procyanidins.

Anthocyanins represented the main group of compounds in the skins, but different proportionalities were observed: $58.6 \%, 36.3 \%$, and $82.2 \%(p<0.05)$ for fresh skin, oven-drying, and freeze-drying, 
respectively, as reported in other studies [30]. This can be explained due to an effect observed in conventional oven-drying, which provided a $52 \%$ reduction in the compounds, while there was a $41 \%$ increase in lyophilization compared to the fresh skin on a dry basis. Malvidin-3,5-di-O-glucoside represented the main compound among anthocyanins at $68 \%, 67 \%$, and $76 \%$, and among all compounds found in the skin at $40 \%, 25 \%$, and $63 \%$ for fresh skin $(536.9 \mathrm{mg} / \mathrm{kg})$, oven-drying $(253.2 \mathrm{mg} / \mathrm{kg})$, and lyophilization $(848.3 \mathrm{mg} / \mathrm{kg})$, respectively. Other anthocyanins found in significant quantity were delphinidin-3-O-glucoside (37.1-115.9 mg/kg), petunidin-3-O-glucoside (25.5-45.3 mg/kg) cyanidin-3-O-glucoside (13.1-59.3 mg/kg), and malvidin-3-O-glucoside (13.5-35.7 mg/kg).

Table 3. Effect of the drying method using the conventional oven-drying and freeze-drying processes in 27 individual phenolic compounds of the BRS magna grape skin residue.

\begin{tabular}{|c|c|c|c|c|}
\hline \multirow{2}{*}{$\begin{array}{l}\text { Phenolic Compounds } \\
\text { (mg/kg) }\end{array}$} & \multicolumn{4}{|c|}{ Method Applied $\ddagger$} \\
\hline & Fresh Peel & Oven-Drying & Freeze-Drying & $p$-Value \\
\hline \multicolumn{5}{|l|}{ Anthocyanins } \\
\hline Cyanidin-3,5-di-O-glucoside & $27.9 \pm 4.1^{\mathrm{a}}$ & $11.8 \pm 0.1^{b}$ & $34.0 \pm 3.7^{\mathrm{a}}$ & $<0.001$ \\
\hline Malvidin-3,5-di-O-glucoside & $536.9 \pm 11.3^{b}$ & $253.2 \pm 5.5^{c}$ & $848.3 \pm 6.7^{\mathrm{a}}$ & $<0.001$ \\
\hline Pelargonidin-3-O-glucoside & $23.5 \pm 1.7^{\mathrm{a}}$ & $14.0 \pm 0.6^{b}$ & $13.1 \pm 1.0^{b}$ & $<0.001$ \\
\hline Delfinidin-3-O-glucoside & $76.6 \pm 2.9^{b}$ & $37.1 \pm 0.6^{c}$ & $115.9 \pm 4.0^{\mathrm{a}}$ & $<0.001$ \\
\hline Cyanidin-3-O-glucoside & $35.7 \pm 5.8^{b}$ & $13.1 \pm 0.1^{\mathrm{c}}$ & $59.3 \pm 6.6^{\mathrm{a}}$ & $<0.001$ \\
\hline Malvidin-3-O-glucoside & $35.7 \pm 4.1^{\mathrm{a}}$ & $16.2 \pm 1.2^{b}$ & $13.5 \pm 1.6^{b}$ & $<0.001$ \\
\hline Peonidina-3-O-glucoside & $2.6 \pm 0.1^{\mathrm{a}}$ & $0.0 \pm 0.0^{\mathrm{c}}$ & $1.5 \pm 0.2^{b}$ & $<0.001$ \\
\hline Petunidin-3-O-glucoside & $45.3 \pm 1.2^{\mathrm{a}}$ & $28.4 \pm 1.2^{b}$ & $25.5 \pm 2.3^{b}$ & $<0.001$ \\
\hline \multicolumn{5}{|l|}{ Flavonols and stilbene } \\
\hline Kaempferol-3-O-glucoside & $13.1 \pm 0.1^{\mathrm{a}}$ & $7.9 \pm 0.1^{b}$ & $4.1 \pm 0.2^{\mathrm{c}}$ & $<0.001$ \\
\hline Rutin & $18.3 \pm 0.1^{\mathrm{a}}$ & $13.1 \pm 0.1^{b}$ & $5.6 \pm 0.5^{c}$ & $<0.001$ \\
\hline Isorhamnetin-3-O-glucoside & $15.7 \pm 1.7^{\mathrm{a}}$ & $10.0 \pm 0.6^{b}$ & $7.6 \pm 0.8^{b}$ & $<0.001$ \\
\hline Myricetin & $0.0 \pm 0.0^{\mathrm{c}}$ & $11.8 \pm 0.1^{\mathrm{a}}$ & $4.1 \pm 0.2^{b}$ & $<0.001$ \\
\hline Trans-resveratrol & $7.8 \pm 0.1^{\mathrm{a}}$ & $5.2 \pm 0.1^{b}$ & $1.3 \pm 0.1^{\mathrm{c}}$ & $<0.001$ \\
\hline Quercetin-3- $\beta$-d-glucoside & $99.3 \pm 7.0^{b}$ & $138.4 \pm 3.2^{\mathrm{a}}$ & $17.2 \pm 2.1^{\mathrm{c}}$ & $<0.001$ \\
\hline \multicolumn{5}{|l|}{ Phenolic acid } \\
\hline Gallic acid & $30.5 \pm 2.3^{\mathrm{a}}$ & $22.7 \pm 1.5^{b}$ & $15.3 \pm 2.7^{c}$ & $<0.001$ \\
\hline Caftaric acid & $32.2 \pm 1.2^{b}$ & $86.0 \pm 0.6^{\mathrm{a}}$ & $24.6 \pm 2.6^{c}$ & $<0.001$ \\
\hline Caffeic acid & $1.6 \pm 0.1^{b}$ & $2.4 \pm 0.1^{\mathrm{a}}$ & $1.6 \pm 0.2^{b}$ & $<0.001$ \\
\hline Ferulic acid & $18.3 \pm 0.1^{\mathrm{a}}$ & $10.5 \pm 0.1^{b}$ & $5.9 \pm 0.2^{c}$ & $<0.001$ \\
\hline Chlorogenic acid & $20.1 \pm 1.2^{\mathrm{a}}$ & $20.0 \pm 0.6^{\mathrm{a}}$ & $7.8 \pm 0.8^{b}$ & $<0.001$ \\
\hline$p$-Coumaric acid & $33.1 \pm 4.6^{\mathrm{a}}$ & $30.6 \pm 1.5^{\mathrm{a}}$ & $15.5 \pm 1.4^{b}$ & $<0.001$ \\
\hline \multicolumn{5}{|l|}{ Flavanols } \\
\hline (-)-Epicatechin & $17.4 \pm 1.2^{b}$ & $22.7 \pm 1.5^{\mathrm{a}}$ & $4.3 \pm 0.4^{\mathrm{c}}$ & $<0.001$ \\
\hline (-)-Epicatechin gallate & $68.8 \pm 4.6^{\mathrm{a}}$ & $48.5 \pm 1.7^{b}$ & $35.8 \pm 3.1^{\mathrm{c}}$ & $<0.001$ \\
\hline (-)-Epigalatocatechin gallate & $68.8 \pm 6.4^{\mathrm{a}}$ & $44.5 \pm 0.9^{b}$ & $22.7 \pm 0.5^{c}$ & $<0.001$ \\
\hline$(+)$-Catechin & $30.5 \pm 2.3^{\mathrm{a}}$ & $26.6 \pm 0.6^{\mathrm{ab}}$ & $24.6 \pm 2.7^{b}$ & 0.034 \\
\hline \multicolumn{5}{|l|}{ Procyanidins } \\
\hline Procyanidin A2 & $20.9 \pm 0.1^{\mathrm{a}}$ & $15.7 \pm 0.1^{b}$ & $5.9 \pm 0.2^{c}$ & $<0.001$ \\
\hline Procyanidin B1 & $36.6 \pm 5.2^{b}$ & $62.9 \pm 2.6^{\mathrm{a}}$ & $13.8 \pm 2.0^{\mathrm{c}}$ & $<0.001$ \\
\hline Procyanidin B2 & $20.0 \pm 2.3^{b}$ & $77.7 \pm 4.9^{\mathrm{a}}$ & $20.0 \pm 2.6^{b}$ & $<0.001$ \\
\hline Total compounds & $1337.2 \pm 71.1^{\mathrm{a}}$ & $1031.0 \pm 29.2^{b}$ & $1351.5 \pm 49.2^{\mathrm{a}}$ & $<0.001$ \\
\hline
\end{tabular}

$\ddagger$ The values of mean \pm standard deviation (SD) correspond to averages from three replicates. Different letters on the same line indicate significant differences between the values $(p<0.05)$.

Flavanols were the second set of major compounds in phenol group whose concentration was $13.9 \%$, $13.8 \%$, and $6.5 \%$ for fresh skin $(185.5 \mathrm{mg} / \mathrm{kg})$, in oven-drying process $(142.3 \mathrm{mg} / \mathrm{kg})$, and freeze-drying $(87.4 \mathrm{mg} / \mathrm{kg})$, respectively, among which the compounds epicatechin gallate (35.8-68.8 mg/kg) and epigallatocatechin gallate $(22.7-68.8 \mathrm{mg} / \mathrm{kg})$ were the main representatives. In addition, there was a 
statistically significant decrease (12.8\% and 19\%) in the amount of flavonoids between fresh skin and materials obtained by conventional drying and freeze-drying $(p<0.05)$, but not between the drying processes $(p>0.05)$.

Quercetin-3- $\beta$-d-glucoside was the main component of flavonols, varying its concentration from 17 to $138 \mathrm{mg} / \mathrm{kg}$, which represented $64.9 \%, 74.3 \%$, and $43.1 \%$ of the total fresh skin compounds, conventional drying, and freeze-drying, respectively. With the exception of quercetin-3- $\beta$-d-glucoside and myricetin, all other compounds in this group had a reduction caused by the drying process $(p<0.05)$, e.g., kaempferol-3-O-glucoside of $39.7 \%$ and $68.7 \%$, rutin of $28.4 \%$ and $69.4 \%$, isorhamnetin-3-O-glucoside of $36.3 \%$ and $51.6 \%$, and trans-resveratrol of $33.3 \%$ and $83.3 \%$ due to conventional drying and freeze-drying, respectively, compared to fresh peel on a dry basis.

The main phenolic acids found were $p$-coumaric $(15.5-33.1 \mathrm{mg} / \mathrm{kg})$, caftaric $(24.6-86.0 \mathrm{mg} / \mathrm{kg})$, and gallic acids $(15.3-30.5 \mathrm{mg} / \mathrm{kg})$. However, this group represented only $10.2 \%, 16.7 \%$, and $5.2 \%$ of the total polyphenols that make up the bark residue of the BRS magna grape. The negative drying effects can be seen due to the lower concentration of gallic, ferulic acid, chlorogenic, and $p$-coumaric acids in $25.6 \%$ and $49.8 \%(p<0.05), 42.6 \%$ and $67.8 \%(p<0.05), 0.5 \%(p>0.05)$ and $53.2 \%(p<0.05)$. A similar effect was observed in procyanidin A2, which decreased $24.9 \%$ and $72 \%$ in conventional drying and freeze-drying, respectively, compared to fresh peel on a dry basis. On the other hand, conventional drying caused an increase in the amount of procyanidin B1 and procyanidin B2 compounds of $71.9 \%$ and $288.5 \%$.

In recent years, several studies have been carried out to evaluate the effect of different drying methods (thermo-degradation/thermo-protection) on grape phenolic compounds, grape marc [5,16,31]. These studies, according to the results presented in this work, affirm that the drying temperature below $70{ }^{\circ} \mathrm{C}$ and the lyophilization process preserve a good part of the bioactive compounds (phenolics).

\subsection{Total Phenolic, Anthocyanin, and Flavonoid Contents and Antioxidant Activity}

Table 4 shows the effect of conventional and freeze-drying on total phenolic compounds, total flavonoids, total anthocyanins, and antioxidant activity of BRS magna grape skin residues. The skin residues of fresh BRS magna grapes showed a high concentration of total phenolic content (TPC, $489.5 \pm 1.8 \mathrm{mg} / 100 \mathrm{~g}$ of material, as GAE), total anthocyanin content (TAC, $124.9 \pm 2.7 \mathrm{mg} / 100 \mathrm{~g}$ of material, as CE), and the total flavonoid content (TFC, $26.0 \pm 0.6 \mathrm{mg} / 100 \mathrm{~g}$ of material, as QE). However, TPC and TFC had a reduction in comparison with the residues of fresh peel (control) of $69.3 \%$ and $69.7 \%$ and $31.2 \%$ and $51.2 \%(p<0.05)$, but an increase in TAC of $20.7 \%$ and $108.3 \%(p<0.05)$ in conventional drying and lyophilization, respectively. The variation in the levels of polyphenols and antioxidant activity according to the drying conditions applied has been observed in previous studies [5,15,18,32]. The conditions of thermal processing apparently have a significant effect on these parameters. Heat treatment can cause damage to the cellular structures of grape pulp tissues and result in easier extraction of antioxidant constituents [17]. It is interesting to note that the contents of some compounds after the drying processes were significantly $(p<0.05)$ higher when compared to fresh skin and freeze-drying sample, i.e., quercetin-3- $\beta$-d-glucoside, caffeic acid, and procyanidins, as shown in Table 3 and supported by the results of antioxidant activity (Table 4).

The amount of TPC observed in the present study was greater than in some grape varieties. Lago-Vanzela et al. [33] for the Bordô grape (Vitis labrusca) reported TPC values $113.0 \mathrm{mg} . \mathrm{GAE} / 100 \mathrm{~g}$ of fresh grape, being $103.4 \mathrm{mg} . \mathrm{GAE} / 100 \mathrm{~g}$ (93.7\%) in the skin and $9.6 \mathrm{mg} . \mathrm{GAE} / 100 \mathrm{~g}(6.3 \%)$ in the pulp. Lima et al. [34] for juices produced using the varieties Isabel Precoce, BRS Cora, BRS Violeta, BRS Magna, Blend Isabel Precoce (80\%) and BRS Violeta $(20 \%)$, and Blend Isabel Precoce (80\%) and BRS Cora (20\%) found TPC values around 77.9-271.2 mg.GAE/100 mL. In addition, Pintać et al. [35] reported an amount of TPC in grape marc extracts (80\% EtOH) of 426, 193, 237, and $287 \mathrm{mg} . \mathrm{GAE} / 100 \mathrm{~g}$ for Cabernet Sauvignon, Merlot, Italian Riesling Agner, and Italian Riesling Bajilo, respectively. However, Tavares et al. [15] recently reported higher TPC values of 815, 834, and $898 \mathrm{mg} . \mathrm{GAE} / \mathrm{g}$ for BRS Violet bagasse even after drying on a foam mat at 60,70 , and $80^{\circ} \mathrm{C}$, respectively. Rockenbach et al. [36] showed 
that the grape skins of the varieties Isabel, Cabernet Sauvignon, and Primitivo showed considerable high concentrations of phenolics, around 1065-1839 mg.CE/100 g, while the values of Pinot Noir, Sangiovese, and Negro Amaro ranged from 660 to $750 \mathrm{mg} . \mathrm{CE} / 100 \mathrm{~g}$, which are values close to those found in this work for the fresh skin residues of the BRS magna grape (Table 4).

Table 4. Effect of the drying method using conventional oven-drying and freeze-dryingprocesses in the total phenolic, total flavonoid, total anthocyanin, and antioxidant activity of the BRS magna grape skin residue.

\begin{tabular}{|c|c|c|c|c|}
\hline \multirow{2}{*}{$\begin{array}{c}\text { Parameters } \\
\text { (\% Dry Weight) }\end{array}$} & \multicolumn{3}{|c|}{ Method Applied $\ddagger$} & \multirow[b]{2}{*}{$p$-Value } \\
\hline & Fresh Peel & Oven-Drying & Freeze-Drying & \\
\hline Total phenolic (mg.GAE/100 g) & $489.5 \pm 1.8^{\mathrm{a}}$ & $149.9 \pm 1.4^{b}$ & $148.3 \pm 0.9^{b}$ & $<0.001$ \\
\hline Total anthocyanin (mg.CE/100 g) & $124.9 \pm 2.7^{c}$ & $150.7 \pm 0.9^{b}$ & $260.1 \pm 4.6^{\mathrm{a}}$ & $<0.001$ \\
\hline Total flavonoids (mg.QE/100 g) & $2.6 \pm 0.1^{\mathrm{a}}$ & $1.8 \pm 0.1^{\mathrm{b}}$ & $1.3 \pm 0.1^{\mathrm{c}}$ & $<0.001$ \\
\hline $\mathrm{DPPH}\left(\mathrm{EC}_{50}\right.$ in $\left.\mu \mathrm{g} / \mathrm{mL}\right)$ & $1.3 \pm 0.2^{c}$ & $3.8 \pm 0.1^{\mathrm{b}}$ & $5.0 \pm 0.1^{\mathrm{a}}$ & $<0.001$ \\
\hline $\operatorname{FRAP}\left(\mu \mathrm{mol} . \mathrm{Fe}^{2+} / \mathrm{g}\right)$ & $184.1 \pm 8.9^{\mathrm{a}}$ & $163.5 \pm 10.9^{a}$ & $82.9 \pm 9.3^{b}$ & $<0.001$ \\
\hline
\end{tabular}

Anthocyanins are the main group of polyphenolic compounds in the BRS magna grape skins, as shown in Tables 3 and 4. Evidently, this characteristic is due its origin deriving from the crossing of the varieties "BRS Rúbea" and "IAC 1398-21 (Traviú)", both with characteristics of violet color [34]. Therefore, the skin of this new hybrid grape variety can be considered an excellent source for exploring this component $[7,13]$. The TAC observed in the skin was close to the values reported by Lago-Vanzela et al. [33] for the Bordô grape skin (Vitis labrusca) of $135.9 \mathrm{mg} / 100 \mathrm{~g}$, as malvidin-3,5-diglucoside equivalents. However, it was superior to the results presented by Lima et al. [34] for grape juices produced from six new Brazilian varieties planted in the Northeast region of Brazil, including BRS magna, which presented concentrations in the range of $0.6-17 \mathrm{mg} / 100 \mathrm{~mL}$, including cyanidin-3,5-glucoside. Anthocyanins represent the main group of polyphenols, as reported in previous studies in other peels of violaceous grapes [34,36].

In this study, the TFC values were higher than those observed by Lima et al. [34] of $7.2-11.1 \mathrm{mg} / 100 \mathrm{~mL}$ for juices produced by different varieties. However, it was similar to those reported by Pintać et al. [35] for Merlot bagasse extracts of $24 \mathrm{mg} . \mathrm{QE} / 100 \mathrm{~g}$, and less than that found (65-74 mg.QE/100 g) in Cabernet Sauvignon, Italian Riesling Agner, and Italian Riesling Bajilo. In addition, Isabel, Sangiovese, Cabernet Sauvignon, and Primitivo grapes presented TFC concentrations that ranged from 156 to $252 \mathrm{mg} / 100 \mathrm{~g}$, as equivalent to catechin [36].

The results of DPPH and FRAP indicate that the BRS magna grape residue extract showed high antioxidant activity in the fresh skin, as well as in the materials obtained by drying in the oven and in the lyophilization process (Table 4). The antioxidant activity (DPPH and FRAP) was higher in the skins obtained by conventional drying, as seen in Table 4. The phenolic acids (gallic acid, caftaric acid, caffeic acid, ferulic acid, chlorogenic acid, and p-coumaric acid) and flavanols (epicatechin, epicatechin gallate, epigalatocatechin gallate, and catechin) are compounds related to antioxidant activity (Table 3). These have higher values than those obtained by freeze-drying. In addition, as shown in Table 4, the value of total flavonoids was higher in samples obtained from oven-drying.

These assays have been widely used to assess the antioxidant capacity of extracts from different foods and products $[4,15,17,18,31]$. The reduction of the DPPH free radical is determined by decreasing its absorption when the color of the DPPH test solution changes from purple to light yellow. Therefore, the antioxidant potential of grape residue extract corresponds to the degree of discoloration [18], while the reduction in the ability to transfer electrons to a $\mathrm{Fe}^{3+} /$ tripyridyl triazine reagent measures the antioxidant power by the FRAP method [15].

The DPPH of the fresh skin residues of the BRS magna grape was $1.7 \pm 0.2 \mu \mathrm{g} / \mathrm{mL}$, as $\mathrm{EC}_{50}$, and the FRAP was $184.1 \mu \mathrm{mol} / \mathrm{g}$ of bark residues, as equivalent to $\mathrm{Fe}_{2} \mathrm{SO}_{4}$. A decrease in antioxidant power 
was observed by DPPH $\left(3.8 \pm 0.1 \mu \mathrm{g} / \mathrm{mL}\right.$ and $4.9 \pm 0.1 \mu \mathrm{g} / \mathrm{mL}$, as $\left.\mathrm{EC}_{50}\right)$ and FRAP $(163.5 \pm 10.9 \mu \mathrm{mol} / \mathrm{g}$ and $82.9 \pm 9.3 \mu \mathrm{mol} / \mathrm{g}$ of skin as equivalent to $\mathrm{Fe}_{2} \mathrm{SO}_{4}$ ) due to conventional drying and lyophilization, respectively. The decline in antioxidant activity is partially related to the reduction in the concentration of polyphenols, as well as to the phenomena of oxidative degradation and polymerization-condensation of some compounds $[5,16]$. In addition, the results observed in the present study are in agreement with other studies reporting that the phenolic content and antioxidant activity were affected by cooking processes, such as steam, boiling, and drying. Variations in total phenolic content and antioxidant activity according to drying conditions have been reported previously [17,18,32].

Recently, Ramón-Gonçalves et al. [32] observed that the temperature influenced the conditions of experimental extraction to obtain the maximum response of polyphenols from used coffee beans. The extraction was carried out with different hydroalcoholic solutions (EtOH: $\mathrm{H}_{2} \mathrm{O}$, 50:50, 40:60, and 30:70, $v / v)$, modification times $(15,23$, or $30 \mathrm{~min})$ and temperatures $\left(80,100\right.$, and $\left.120^{\circ} \mathrm{C}\right)$. The extraction of the three conditions using the lowest temperature of $80^{\circ} \mathrm{C}$ exhibited the highest content of polyphenols and antioxidant activity, where the best results were obtained at the temperature of $80{ }^{\circ} \mathrm{C}$ for $30 \mathrm{~min}$ with a mixture of EtOH: $\mathrm{H}_{2} \mathrm{O}, 50: 50(v / v)$. In addition, some compounds have been shown to have areater influence on temperature during extraction (e.g., rutin). The extracts obtained under these conditions are characterized by high values of the total flavonoid content, in the range of 110-560 mg.QE/100 g dw and total polyphenol content of 140-450 mg.GAE/100 g dw. Planinić et al. [31] showed that drying at higher temperatures and a prolonged process have a greater impact on antioxidant activity, when compared to drying treatment at milder temperatures and shorter periods. Grape marc extracts that were dried for $180 \mathrm{~min}$ at $80^{\circ} \mathrm{C}$ showed $20 \%$ less antioxidant activity, while the grape marc sample dried for $90 \mathrm{~min}$ at $60{ }^{\circ} \mathrm{C}$ had $11.43 \%$ lower neutralization capacity (DPPH), compared to fresh peel extract. In the present study, the antioxidant activity of the grape skin residue was influenced by thermal reactions [5], possibly due to the polyphenols of low molecular weight that were generated from the enzymatic hydrolysis of polymeric polyphenols from the cellulose matrix [37].

\subsection{Correlation between Color Parameters and Antioxidant Activity with Phenolic Compounds}

Figure 2 shows the $r$ values for Pearson's correlation between the contents of bioactive compounds and the results of the color parameters, depending on the treatment. There is a high correlation (above 0.9) between the brightness parameter for TAC (Figure 2a) and TFC (Figure 2b), but the correlation was positive for TAC $(r=0.9731)$ and negative for TFC $(r=-0.9375)$, as an effect of heat treatment. Close results were also observed between the chromaticity parameters with TAC (Figure 2c) and TFC (Figure 2d). The degree of correlation between these parameters has also been reported by previous studies [4,33].

Figure 3 shows the $r$ values for the correlation between the total phenolic content and the antioxidant activity. A high correlation $(r=-0.9560)$ was observed between the total phenolic content and the free radical scavenging activity (Figure $3 a$ ) and the reducing ferric antioxidant power (Figure 3b). Important correlations between phenolic compounds and the antioxidant capacity of grape residue extracts have been observed in other studies $[37,38]$ as well as in the present study.

Martins et al. [37] reported a correlation between polyphenolic compounds (quercetin, trans-resveratrol, gallic acid, caffeic acid, caffeic acid, catechin, and procyanidin B2) and antioxidant activity in white grape peel in the ranges of $0.414-0.778$ for DPPH and 0.899 to insignificant ranges for FRAP results. Although the increase in DPPH values was correlated with all the phenolic compounds analyzed, FRAP values were correlated to an even stronger degree. Given that $r$ values $\geq 0.6$ indicate a significant correlation, only two polyphenolics, gallic acid and resveratrol, were correlated to all three tests for antioxidant activity. Sir Elkhatim et al. [38] showed a high correlation between antioxidant activity (DPPH) and the level of total phenolic (0.9303), as well as lower correlations with the values of total flavonoids $(r=0.111)$ and vitamin C $(r=0.2021)$, in residues of citrus fruits (grapefruit, lemon, and orange). However, different results were found by $\mathrm{Xu}$ et al. [39] who observed in grape marc a positive correlation of ABTS elimination capacity with the values of TPC and TFC $(r=0.798$ and 0.977), but not with DPPH ( $r=0.018$ and -0.409$)$, respectively. Only TAC showed a positive correlation 
with DPPH $(r=0.991)$. It has been suggested that different phenolic compounds are responsible for tempering different free radicals: flavonoids, tannins, and condensed tannins contribute to the antioxidant capacity of ABTS, while anthocyanins contribute to DPPH.

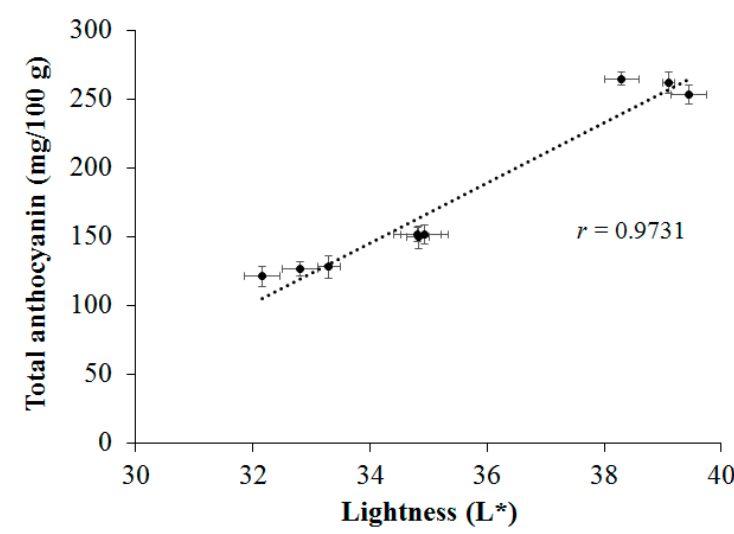

(a)

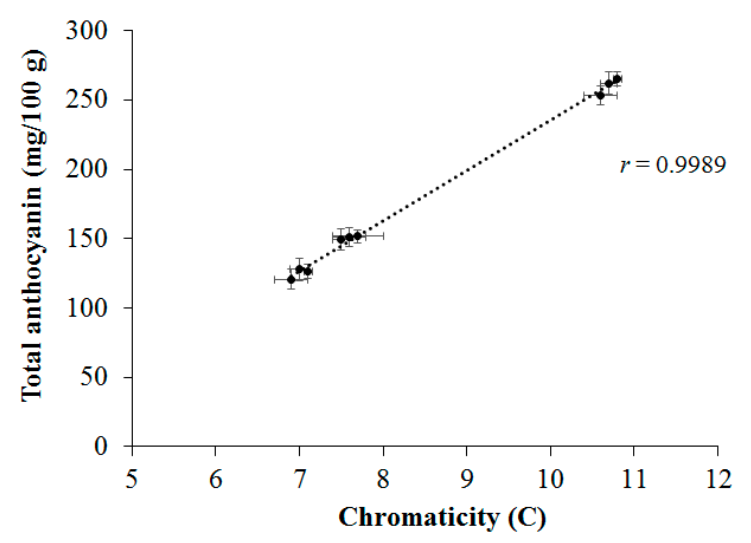

(c)

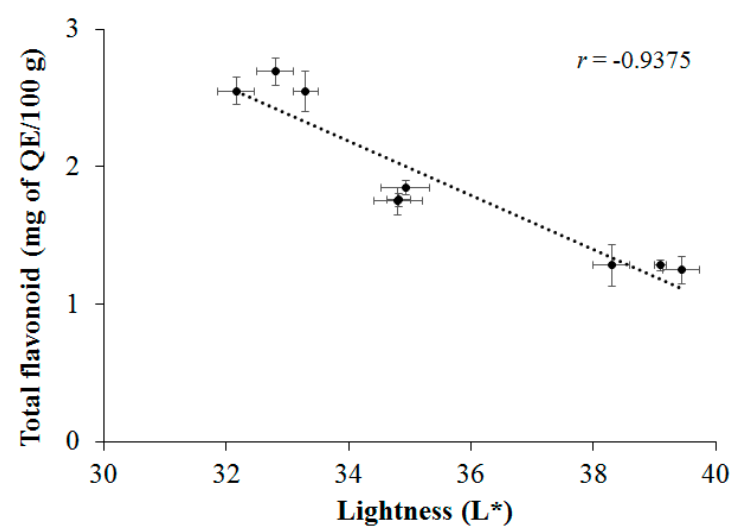

(b)

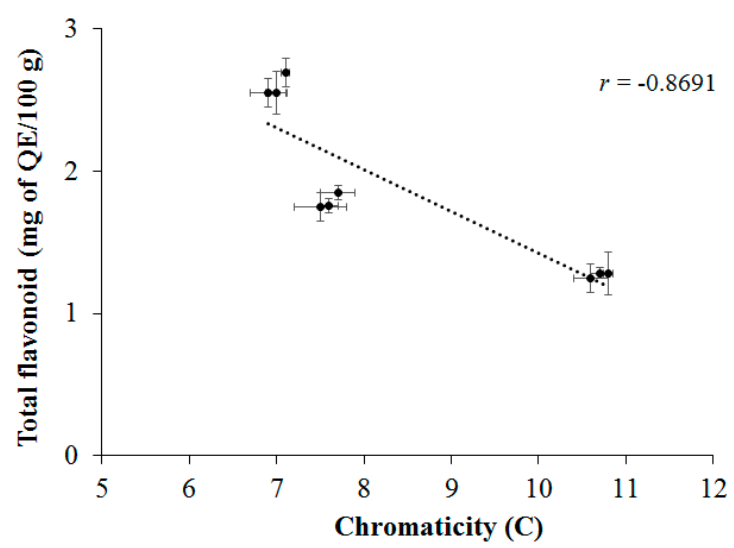

(d)

Figure 2. Correlations between: luminosity and TAC (a), luminosity and TFC (b), chromaticity and TAC (c) and chromaticity and TFC (d). The values of mean \pm standard deviation (SD) correspond to averages from three samples.

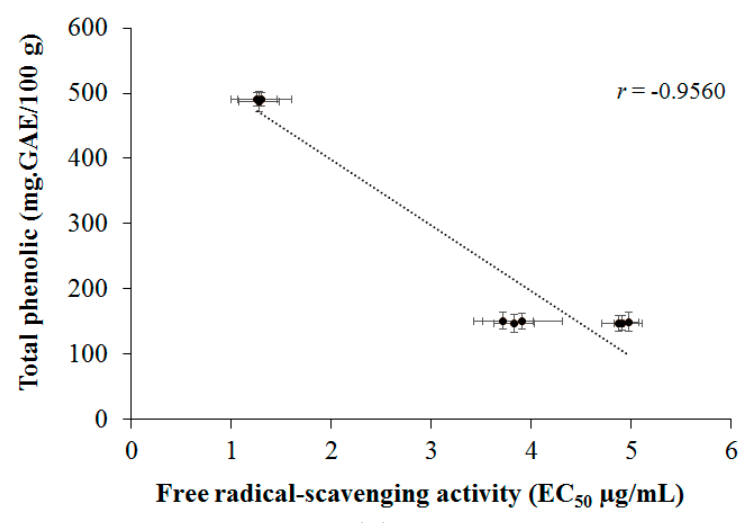

(a)

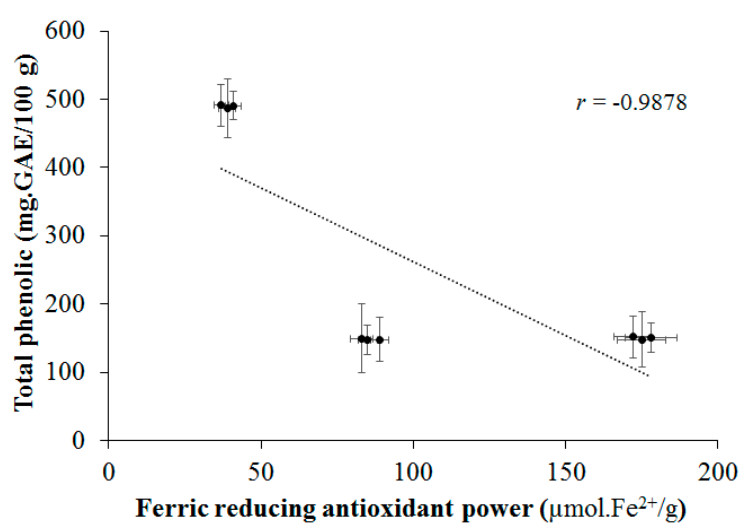

(b)

Figure 3. Correlation: between TPC and the DPPH radical scavenging assay (a); and between TPC and FRAP assay (b). The values of mean \pm standard deviation (SD) correspond to averages from three samples. 


\section{Materials and Methods}

\subsection{Materials}

Folin-Ciocalteau reagent, 2,2-diphenyl-1-picrylhydrazyl (DPPH), 2,4,6-Tris(2-pyridyl)-1,3,5triazine (TPTZ), cyanidin-3,5-di-O-glucoside, malvidin-3,5-di-O-glucoside, pelargonidin-3-O-glucoside, delfinidin-3-O-glucoside, cyanidin-3-O-glucoside, malvidin-3-O-glucoside, peonidina-3-O-glucoside, petunidin-3-O-glucoside, kaempferol-3-O-glucoside, rutin, isorhamnetin-3-O-glucoside, myricetin, trans-resveratrol, quercetin-3- $\beta$-d-glucoside, gallic acid, caftaric acid, caffeic acid, ferulic acid, chlorogenic acid, p-coumaric acid, (-)-epicatechin, (-)-epicatechin gallate, (-)-epigalatocatechin gallate, (+)-catechin, procyanidin A2, procyanidin B1, and procyanidin B2 compounds were purchased from Sigma-Aldrich ${ }^{\circledR}$ (St. Louis, MO, USA). The solvents (methanol, acetonitrile, and ortho-phosphoric acid) used in the extraction and HPLC procedures were analytical/HPLC grade and purchased from Merck $^{\circledR}$ (São Paulo, Brazil).

\subsection{BRS Magna Grape Skin Residue and the Dehydration Process}

The "BRS Magna" grape skins obtained during the 2018 harvest were kindly supplied by a juice company in the São Francisco Valley $\left(9^{\circ} 23^{\prime} 34^{\prime \prime} \mathrm{S}, 40^{\circ} 30^{\prime} 28^{\prime \prime} \mathrm{W}\right.$, Brazil) and transported in a plastic container at $4{ }^{\circ} \mathrm{C}$ to the Food Science Laboratory of the Faculty of Technology (National Industrial Training Service-SENAI/CIMATEC, Salvador, Brazil). The husks were manually separated from the other parts (seeds and stems). The material was packed and stored in freezing conditions $\left(-70{ }^{\circ} \mathrm{C}\right)$ until the dehydration process was applied. The residues of grape skins "BRS Magna" were dried conventionally, being placed in trays, $2.5 \mathrm{~cm}$ thick, in an oven-drying process with air circulation (Q314M, Quimis ${ }^{\circledR}$, Diadema, Brazil) at $65^{\circ} \mathrm{C}$ to constant weight. In dehydration by lyophilization, the sample was left in the Liobras ${ }^{\circledR}$ equipment (model L108, LIOTOP, São Carlos, Brazil) at a vacuum pressure of $4 \times 10^{-2} \mathrm{mBa}$ at a temperature of $-57^{\circ} \mathrm{C}$ for $24 \mathrm{~h}$. Frozen samples of fresh skin (in natura) were used as a control treatment in order to evaluate the effect of dehydration methods on composition, color, phenolic compounds, and antioxidant capacity.

\subsection{Proximate Composition}

The materials were ground (with a $495 \mathrm{~mm}$ sieve) to obtain a uniform particle size. These analyses were performed according to the established methods [40]. Briefly, the moisture content was determined by oven-drying (Q314M, Quimis ${ }^{\circledR}$, Diadema, Brazil) at $105^{\circ} \mathrm{C}$ until constant weight. The crude protein content was calculated by the total nitrogen content $(N \times 5.3)$, using nitrogen distiller equipment (TE036/1, Tecnal ${ }^{\circledR}$, Piracicaba, Brazil). The ash content was obtained in a muffle at $550{ }^{\circ} \mathrm{C}(\mathrm{SP} 2707-21$, Quimis ${ }^{\circledR}$, Diadema, Brazil). The total lipid content was determined by gravimetric analysis after extraction in a Soxhlet device (TE188/6, Tecnal ${ }^{\circledR}$, Piracicaba, Brazil), using petroleum ether for $6 \mathrm{~h}$. The amount of crude fiber was determined through sequential acid (1.25\% sulfuric acid) and alkaline (1.25\% sodium hydroxide) treatments. The carbohydrate content was estimated by calculating the percentage remaining after measuring all other components: \% carbohydrates $=100$ (moisture + protein + lipid + ash). The results are presented in $\mathrm{g} / 100 \mathrm{~g}$ of material on a dry weight $(\mathrm{dw})$.

\subsection{Color Parameters}

Color was evaluated using the parameters CIE Lab for luminosity $\left(\mathrm{L}^{*}\right)$, hue by hue angle $\left(\mathrm{H}^{\circ}\right)$, and color intensity by chromaticity (C), using a $2 \mathrm{~mm}$ bucket length in a CR-400 colorimeter (Konica Minolta ${ }^{\circledR}$, Tokyo, Japan), following the manufacturer's recommendations.

\subsection{Individual Phenolic Compounds by HPLC-DAD-FD}

Individual phenolic compounds were analyzed by high performance liquid chromatography (Waters 269, Aliance System ${ }^{\circledR}$, Water Corporation, Milford, USA) equipped with a diode array detector 
(DAD) and a fluorescence detector (FD). The samples were previously filtered through a $0.45-\mu \mathrm{m}$ nylon membrane (Phenomenex ${ }^{\circledR}$, Torrance, CA, USA) and injected in triplicate $(10 \mu \mathrm{L})$. The conditions were: pre-Gemini-NX C18 column ( $4.0 \mathrm{~mm} \times 3.0 \mathrm{~mm}$, Phenomenex ${ }^{\circledR}$, Torrance, CA, USA), Gemini-NX C18 column $\left(150 \mathrm{~mm} \times 4.60 \mathrm{~mm} \times 3 \mu \mathrm{m}\right.$, Phenomenex ${ }^{\circledR}$, Torrance, CA, USA), temperature from oven at $40^{\circ} \mathrm{C}$, and flow rate of $0.5 \mathrm{~mL} / \mathrm{min}$ of mobile phases, consisting of (A) $0.85 \%$ phosphoric acid solution and (B) acetonitrile. The elution gradient was used as follows: $0 \mathrm{~min}, 100 \% \mathrm{~A} ; 10 \mathrm{~min}, 93 \% \mathrm{~A} ; 20 \mathrm{~min}, 90 \% \mathrm{~A}$; $30 \mathrm{~min}, 88 \% \mathrm{~A} ; 40 \mathrm{~min}, 77 \% \mathrm{~A} ; 45 \mathrm{~min}, 65.0 \% \mathrm{~A}$; and $100 \% \mathrm{~B}$ at $55 \mathrm{~min}$. DAD was used at wavelengths $280 \mathrm{~nm}$ (gallic acid, (-)-epicatechin gallate and (-)-gallate epigallatocatechin), $320 \mathrm{~nm}$ (trans-resveratrol, caffeine, caffeine, caffeic, ferulic, chlorogenic, and $\rho$-coumaric acids), $360 \mathrm{~nm}$ (kaempferol-3-O-glucoside, myricetin, isorhamnetin-3-O-glucoside, rutin, and quercetin-3- $\beta$-D-glucoside), $520 \mathrm{~nm}$ (cyanidin-3,5di-O-glucoside, malvidin-3,5-di-O-glucoside, pelargonidin-3-O-glucoside, delphinidin-3-O-glucoside, cyanidin-3-O-glucoside, malvidin-3-O-glucoside, peonidin-3-O-glucoside, and pethunidine-3-Oglucoside), and fluorescence with $280 \mathrm{~nm}$ excitation and $320 \mathrm{~nm}$ emission ((-)-epicatechin, (+)-catechin, procyanidin A2, procyanidin B1, and procyanidin B2) were used to identify and quantify the compounds. The identification and quantification of phenolic compounds was carried out as a method previously established [29]. The calibration curves were prepared using standards for 27 phenolic compounds (see Figure S1). The linearity of the method consisted of different concentration ranges on the standard calibration curve $(0.625-15.00 \mu \mathrm{g} / \mathrm{mL})$. The regression coefficients equations $\left(\mathrm{R}^{2}\right) \mathrm{ranged}$ 0.9838-0.9999. The theoretical limits of detection varied from 0.001 to $0.190 \mu \mathrm{g} / \mathrm{mL}$, while the theoretical limits of quantification (LOQ) varied from 0.003 to $0.370 \mu \mathrm{g} / \mathrm{mL}$. The average recovery value ranged $98.27-102.01 \%$ (anthocyanins), 86.18-106.50\% (flavonols), $83.97-100.93 \%$ (phenolic acids), and $86.86-97.10 \%$ (tannins). The accuracy of the RSD method ranged $0.73-2.87 \%$ for non-enriched samples and $0.71-9.24 \%$ for enriched samples. For $\mathrm{RSD}_{\mathrm{R}}$, they were $1.99-6.46 \%$ for non-enriched samples and $1.34-9.26 \%$ for enriched samples. The results are presented in $\mathrm{mg} / \mathrm{kg}$, on a dw.

\subsection{Content of Phenolics, Anthocyanins and Flavonoids}

The total phenolic content (TPC) was determined spectrophotometrically (Beckman Spectrophotometer ${ }^{\circledR}$ Coulter DU-70 UV/VIS, California, USA), according to the Folin-Ciocalteau method [41] through the absorbance measured at $750 \mathrm{~nm}$. A calibration curve was constructed using standard gallic acid $(25-200 \mu \mathrm{g} / \mathrm{mL})$ to obtain the equation: $\mathrm{y}=0.0073 \mathrm{x}-0.0591\left(\mathrm{R}^{2}=0.9999\right)$. The results are expressed in mg of gallic acid equivalent (GAE) per $100 \mathrm{~g}$ of samples, on a dw.

The total anthocyanin content (TAC) was determined according to the established method [42], using the absorbance measured at $535 \mathrm{~nm}$ (Beckman spectrophotometer ${ }^{\circledR}$ Coulter DU-70 UV/VIS, Los Angeles, CA, USA). The total anthocyanin content was obtained using the equation: Total anthocyanin content $\mathrm{mg} / \mathrm{L}=(A \times F D) /(\varepsilon \times b)$, where $A$ is the absorbance $(535 \mathrm{~nm})$, $\varepsilon$ denotes the coefficient of absorbance cyanide-3-glucoside (26900, MW 449.2), $b$ corresponds to the bucket thickness $(1 \mathrm{~cm})$, and FD refers to the extract dilution factor. The results are expressed in $\mathrm{mg}$ of cyanidin equivalent (CE) per $100 \mathrm{~g}$ of sample, on a dw.

The total flavonoid content (TFC) was determined by the aluminum chloride colorimetric method [43], using the absorbance measured at $415 \mathrm{~nm}$ (Beckman spectrophotometer ${ }^{\circledR}$ Coulter DU-70 UV/VIS, Los Angeles, CA, USA). A calibration curve $(5-35 \mu \mathrm{g} / \mathrm{mL})$ was constructed from the quercetin standard from Sigma-Aldrich ${ }^{\circledR}$ (CAS 6151-25-3, St. Louis, MO, USA) to obtain the equation: $y=0.0287 x-0.0076$ $\left(R^{2}=0.9986\right)$. The results are expressed in $\mathrm{mg}$ of quercetin equivalent $(\mathrm{QE})$ per $100 \mathrm{~g}$ of sample, on a dw.

\subsection{Antioxidant Activity}

The free radical scavenging activity (DPPH) was evaluated according to the established method [44], where the decrease in absorbance at $515 \mathrm{~nm}$ of DPPH $100 \mathrm{mM}$ dissolved in $80 \%$ methanol is measured in $30 \mathrm{~min}$ after adding the sample. The antioxidant activity is expressed in $\mathrm{EC}_{50} \mu \mathrm{g}$ per $\mathrm{g}$ of samples, on a dry weight. The ferric reducing antioxidant power (FRAP) method was evaluated in the direct measurement of antioxidant capacity (reducing) by reducing the $\mathrm{Fe}^{3+} /$ tripyridyl triazine (TPTZ) 
complex to $\mathrm{Fe}^{2+}$ under acidic $\mathrm{pH}$ (3.6) [45]. The reduction capacity of the samples was determined using the absorbance at $620 \mathrm{~nm}$ (Beckman ${ }^{\circledR}$ Coulter DU-70 UV/VIS, Los Angeles, CA, USA). The results are expressed as $\mu \mathrm{mol} . \mathrm{Fe}^{2+}$ per $\mathrm{g}$ of sample, on a dw.

\subsection{Statistical Analysis}

The averages of the results were evaluated through the one-way analysis of variance (ANOVA). For multiple comparison, the Turkey test (SigmaStat, v. 3.5, Systat ${ }^{\circledR}$ software, Chicago, IL, USA) was used. The level of significance was $p \leq 0.05$. All results are presented as mean \pm standard deviation for at least three independent analyses. Pearson's correlation coefficient ( $r$ ) was used to evaluate the covariance relationships between the content of bioactive compounds and the antioxidant properties of the skin residues of the BRS magna grape.

\section{Conclusions}

In this study, it was observed that the residue (skin) of the BRS magna grape variety has a high concentration of bioactive compounds and antioxidant activity. It was also found that conventional drying in an oven at $65{ }^{\circ} \mathrm{C}$ and freeze drying for $24 \mathrm{~h}$ caused significant changes in color parameters, composition of bioactive compounds, and antioxidant capacity at different intensities, but not in the proximate composition. In addition, it is worth mentioning that there were also positive changes, mainly the increase in antioxidant capacity. It was observed that the best drying method to be applied will depend on the purpose of its use. From the results obtained, while using conventional drying, the highest values obtained were among individual phenolic acids, which are mainly responsible for antioxidant activity (DPPH and FRAP), and among phenolic and total flavonoids. Freeze-drying was more effective in preserving anthocyanins, compounds that are known to be thermolabile.

Supplementary Materials: The Supplementary Materials are available online. Figure S1, Chromatograms of the phenolic compounds and their respective retention time (RT), equation and regression coefficient (R2). To identify and quantify the compounds were used DAD in the wavelengths 280 (a), 320 (b), 360 (c), $520 \mathrm{~nm}$ (d), and fluorescence at $280 \mathrm{~nm}$ excitation and $320 \mathrm{~nm}$ emission (e).

Author Contributions: M.A.U.-G., E.d.S.F., B.A.S.M., and J.I.D. conceived and designed the experiments. G.V.d.S., W.P.d.O., C.F.G.d.S., and C.P.d.Q. performed the experiments (dehydration process, proximate composition, color parameters, determination of the content of phenolics, anthocyanins and flavonoids, and antioxidant activity). G.V.d.S. and C.P.d.Q. performed the experiments (determination of phenolic compounds by HPLC-DAD). E.d.S.F. and C.F.G.d.S. performed the statistical analysis. M.A.U.-G., E.d.S.F., and B.A.S.M. analyzed the data. M.A.U.-G., B.A.S.M., and E.d.S.F. wrote the paper. M.A.U.-G., B.A.S.M., and E.d.S.F. had primary responsibility for the final content. All authors have read and agreed to the published version of the manuscript.

Funding: The authors would like to thank Serviço Nacional de Aprendizagem Industrial—SENAI/CIMATEC (Bahia), Federal University of Bahia (UFBA) for the financially support. Gabriela Viana da Silva's fellowship was financed by Fundação de Amparo à Pesquisado do Estado da Bahia (FAPESB, No. 0118/2015).

Conflicts of Interest: All authors declare no conflict of interest with regard to the described research, the publication of the results, and financial issues.

\section{References}

1. Savini, F. The economy that runs on waste: Accumulation in the circular city. J. Environ. Policy Plan. 2019, 21, 675-691. [CrossRef]

2. Fontana, A.R.; Antoniolli, A.; Bottini, R. Grape pomace as a sustainable source of bioactive compounds: Extraction, characterization, and biotechnological applications of phenolics. J. Agric. Food Chem. 2013, 61, 8987-9003. [CrossRef] [PubMed]

3. Krystosik, A.; Njoroge, G.; Odhiambo, L.; Forsyth, J.E.; Mutuku, F.; LaBeaud, A.D. Solid wastes provide breeding sites, burrows, and food for biological disease vectors, and urban zoonotic reservoirs: A call to action for solutions-based research. Front. Public Heal. 2020, 7, 405. [CrossRef]

4. Amorim, F.L.; Silva, M.B.C.; Cirqueira, M.G.; Oliveira, R.S.; Machado, B.A.S.; Gomes, R.G.; Souza, C.O.; Druzian, J.I.; de Souza Ferreira, E.; Umsza-Guez, M.A. Grape peel (Syrah var.) jam as a polyphenol-enriched functional food ingredient. Food Sci. Nutr. 2019, 7, 1584-1594. [CrossRef] [PubMed] 
5. Pedroza, M.A.; Carmona, M.; Pardo, F.; Salinas, M.R.; Zalacain, A. Waste grape skins thermal dehydration: Potential release of colour, phenolic and aroma compounds into wine. CYTA J. Food. 2012, 10, 225-234. [CrossRef]

6. $\quad$ Falcão, J.S.; Sobral, T.S.; Cruz, L.F.S.; Philadelpho, B.O.; Santos, J.E.M.; Costa, J.A.V.; Druzian, J.I.; Ferreira, E.S. Protein-enriched umbu (Spondias tuberosa) jam prepared by supplementation with Spirulina sp. LEB-18. Brazilian J. Dev. 2020, 6, 22714-22729. [CrossRef]

7. Makris, D.P.; Şahin, S. Polyphenolic antioxidants from agri-food waste biomass. Antioxidants 2019, 8, 624 . [CrossRef]

8. Devesa-Rey, R.; Vecino, X.; Varela-Alende, J.L.; Barral, M.T.; Cruz, J.M.; Moldes, A.B. Valorization of winery waste vs. the costs of not recycling. Waste Manag. 2011, 31, 2327-2335. [CrossRef]

9. Cory, H.; Passarelli, S.; Szeto, J.; Tamez, M.; Mattei, J. The role of polyphenols in human health and food systems: A mini-Review. Front. Nutr. 2018, 5, 87. [CrossRef]

10. Fraga, C.G.; Croft, K.D.; Kennedy, D.O.; Tomás-Barberán, F.A. The effects of polyphenols and other bioactives on human health. Food Funct. 2019, 10, 514-528. [CrossRef]

11. Sharma, R.; Padwad, Y. Plant polyphenol-based second-generation synbiotic agents: Emerging concepts, challenges, and opportunities. Nutrition 2020, 77, 110785. [CrossRef] [PubMed]

12. Pedroza, M.A.; Carmona, M.; Alonso, G.L.; Salinas, M.R.; Zalacain, A. Pre-bottling use of dehydrated waste grape skins to improve colour, phenolic and aroma composition of red wines. Food Chem. 2013, 136, 224-236. [CrossRef] [PubMed]

13. Cortez, R.; Luna-Vital, D.A.; Margulis, D.; Gonzalez de Mejia, E. Natural pigments: Stabilization methods of anthocyanins for food applications. Compr. Rev. Food Sci. Food Saf. 2017, 16, 180-198. [CrossRef]

14. Caldas, T.W.; Mazza, K.E.L.; Teles, A.S.C.; Mattos, G.N.; Brígida, A.I.S.; Conte-Junior, C.A.; Borguini, R.G.; Godoy, R.L.O.; Cabral, L.M.C.; Tonon, R.V. Phenolic compounds recovery from grape skin using conventional and non-conventional extraction methods. Ind. Crops Prod. 2018, 111, 86-91. [CrossRef]

15. Tavares, I.M.C.; Castilhos, M.B.M.; Mauro, M.A.; Ramos, A.M.; Souza, R.T.; Gómez-Alonso, S.; Gomes, E.; Da-Silva, R.; Hermosín-Gutiérrez, I.; Lago-Vanzela, E.S. BRS Violeta (BRS Rúbea $\times$ IAC 1398-21) grape juice powder produced by foam mat drying. Part I: Effect of drying temperature on phenolic compounds and antioxidant activity. Food Chem. 2019, 298, 124971. [CrossRef]

16. Teles, A.S.C.; Chávez, D.W.H.; Gomes, F.S.; Cabral, L.M.C.; Tonon, R.V. Effect of temperature on the degradation of bioactive compounds of Pinot Noir grape pomace during drying. Brazilian J. Food Technol. 2018, 21. [CrossRef]

17. Ruttarattanamongkol, K.; Chittrakorn, S.; Weerawatanakorn, M.; Dangpium, N. Effect of drying conditions on properties, pigments and antioxidant activity retentions of pretreated orange and purple-fleshed sweet potato flours. J. Food Sci. Technol. 2016, 53, 1811-1822. [CrossRef]

18. Vodnar, D.C.; Călinoiu, L.F.; Dulf, F.V.; Ştefănescu, B.E.; Crişan, G.; Socaciu, C. Identification of the bioactive compounds and antioxidant, antimutagenic and antimicrobial activities of thermally processed agro-industrial waste. Food Chem. 2017, 231, 131-140. [CrossRef]

19. Antoniolli, A.; Fontana, A.R.; Piccoli, P.; Bottini, R. Characterization of polyphenols and evaluation of antioxidant capacity in grape pomace of the cv. Malbec. Food Chem. 2015, 178, 172-178. [CrossRef]

20. Babbar, N.; Oberoi, H.S.; Sandhu, S.K. Therapeutic and nutraceutical potential of bioactive compounds extracted from fruit residues. Crit. Rev. Food Sci. Nutr 2015, 55, 319-337. [CrossRef]

21. Grosso, G. Effects of polyphenol-rich foods on human health. Nutrients 2018, 10, 1089. [CrossRef] [PubMed]

22. Sharma, R.; Padwad, Y. Perspectives of the potential implications of polyphenols in influencing the interrelationship between oxi-inflammatory stress, cellular senescence and immunosenescence during aging. Trends Food Sci. Technol. 2020, 98, 41-52. [CrossRef]

23. Tresserra-Rimbau, A.; Lamuela-Raventos, R.M.; Moreno, J.J. Polyphenols, food and pharma. current knowledge and directions for future research. Biochem. Pharmacol. 2018, 156, 186-195. [CrossRef] [PubMed]

24. Zillich, O.V.; Schweiggert-Weisz, U.; Eisner, P.; Kerscher, M. Polyphenols as active ingredients for cosmetic products. Int. J. Cosmet. Sci. 2015, 37, 455-464. [CrossRef] [PubMed]

25. García-Lomillo, J.; González-SanJosé, M.L. Applications of wine pomace in the food industry: Approaches and functions. Compr. Rev. Food Sci. Food Saf. 2017, 156, 186-195. [CrossRef]

26. Belović, M.; Torbica, A.; Pajić-Lijaković, I.; Mastilović, J. Development of low calorie jams with increased content of natural dietary fibre made from tomato pomace. Food Chem. 2017, 237, 1226-1233. [CrossRef] 
27. Gowman, A.C.; Picard, M.C.; Rodriguez-Uribe, A.; Misra, M.; Khalil, H.; Thimmanagari, M.; Mohanty, A.K. Physicochemical analysis of apple and grape pomaces. BioResources 2019, 14, 3210-3230. [CrossRef]

28. Botelho, T.; Costa, M.; Wilk, M.; Magdziarz, A. Evaluation of the combustion characteristics of raw and torrefied grape pomace in a thermogravimetric analyzer and in a drop tube furnace. Fuel 2018, 212, 95-100. [CrossRef]

29. Natividade, M.M.P.; Corrêa, L.C.; Souza, S.V.C.; Pereira, G.E.; Lima, L.C.O. Simultaneous analysis of 25 phenolic compounds in grape juice for HPLC: Method validation and characterization of São Francisco Valley samples. Microchem. J. 2013, 110, 665-674. [CrossRef]

30. Alencar, N.M.M.; Cazarin, C.B.B.; Corrêa, L.C.; Maróstica Junior, M.R.; Biasoto, A.C.T.; Behrens, J.H. Influence of maceration time on phenolic compounds and antioxidant activity of the Syrah must and wine. J. Food Biochem. 2018, 42, e12471. [CrossRef]

31. Planinic, M.; Aliakbarian, B.; Perego, P.; Greganic, K.; Tomas, S.; Bucic-Kojic, A. Influence of temperature and drying time on extraction yield of phenolic compounds from grape pomace variety "portogizac". Chem. Biochem. Eng. Q. 2015, 29, 343-350. [CrossRef]

32. Ramón-Gonçalves, M.; Alcaraz, L.; Pérez-Ferreras, S.; León-González, M.E.; Rosales-Conrado, N.; López, F.A. Extraction of polyphenols and synthesis of new activated carbon from spent coffee grounds. Sci. Rep. 2019, 9,1-11. [CrossRef] [PubMed]

33. Lago-Vanzela, E.S.; Da-Silva, R.; Gomes, E.; García-Romero, E.; Hermosín-Gutiérrez, I. Phenolic composition of the edible parts (flesh and skin) of bordô grape (Vitis labrusca) using HPLC-DAD-ESI-MS/MS. J. Agric. Food Chem. 2011, 59, 13136-13146. [CrossRef]

34. Lima, M.D.S.; Silani, I.D.S.V.; Toaldo, I.M.; Corrêa, L.C.; Biasoto, A.C.T.; Pereira, G.E.; Bordignon-Luiz, M.T.; Ninow, J.L. Phenolic compounds, organic acids and antioxidant activity of grape juices produced from new Brazilian varieties planted in the Northeast Region of Brazil. Food Chem. 2014, 161, 94-103. [CrossRef]

35. Pintać, D.; Majkić, T.; Torović, L.; Orčić, D.; Beara, I.; Simin, N.; Mimica-Dukić, N.; Lesjak, M. Solvent selection for efficient extraction of bioactive compounds from grape pomace. Ind. Crops Prod. 2018, 111, 379-390. [CrossRef]

36. Rockenbach, I.I.; Gonzaga, L.V.; Rizelio, V.M.; Gonçalves, A.E.d.S.S.; Genovese, M.I.; Fett, R. Phenolic compounds and antioxidant activity of seed and skin extracts of red grape (Vitis vinifera and Vitis labrusca) pomace from Brazilian winemaking. Food Res. Int. 2011, 44, 897-901. [CrossRef]

37. Martins, I.M.; Roberto, B.S.; Blumberg, J.B.; Chen, C.Y.O.; Macedo, G.A. Enzymatic biotransformation of polyphenolics increases antioxidant activity of red and white grape pomace. Food Res. Int. 2016, 89, 533-539. [CrossRef]

38. Sir Elkhatim, K.A.; Elagib, R.A.A.; Hassan, A.B. Content of phenolic compounds and vitamin C and antioxidant activity in wasted parts of Sudanese citrus fruits. Food Sci. Nutr. 2018, 6, 1214-1219. [CrossRef]

39. Xu, Y.; Burton, S.; Kim, C.; Sismour, E. Phenolic compounds, antioxidant, and antibacterial properties of pomace extracts from four virginia-grown grape varieties. Food Sci. Nutr. 2016, 4, 125-133. [CrossRef]

40. AOAC. Official Methods of Analysis, 18th ed.; Association of Official Analytical Chemists: Gaithersburg, MD, USA, 2005.

41. Singleton, V.L.; Rossi, J.A. Colorimetry of total phenolics with phosphomolybdic-phosphotungstic acid reagents. Am. J. Enol. Vitic. 1965, 16, 144-158.

42. Lees, D.; Francis, F. Standardization of pigment analyses in cranberries. HortSci. 1972, 7, 83-84.

43. Chang, C.C.; Yang, M.H.; Wen, H.M.; Chern, J.C. Estimation of total flavonoid content in propolis by two complementary colometric methods. J. Food Drug Anal. 2002, 10, 178-182. [CrossRef]

44. Brand-Williams, W.; Cuvelier, M.E.; Berset, C. Use of a free radical method to evaluate antioxidant activity. LWT Food Sci. Technol. 1995, 28, 25-30. [CrossRef]

45. Benzie, I.F.F.; Strain, J.J. The ferric reducing ability of plasma (FRAP) as a measure of "antioxidant power": The FRAP assay. Anal. Biochem. 1996, 239, 70-76. [CrossRef]

Sample Availability: Samples of the material are available from the authors.

(C) 2020 by the authors. Licensee MDPI, Basel, Switzerland. This article is an open access article distributed under the terms and conditions of the Creative Commons Attribution (CC BY) license (http://creativecommons.org/licenses/by/4.0/). 